\title{
最近経 験した半月板囊腫
}

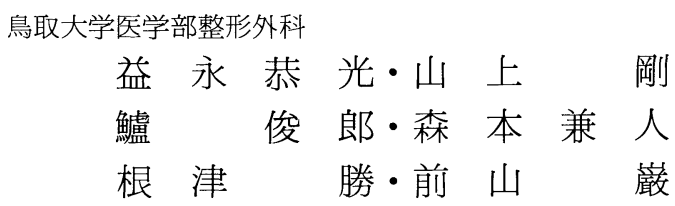

Cysts of the Menisci of the Knee

by

\section{Yasumitsu Masunaga, Takeshi Yamagami, Toshiro Suzuki Kaneto Morimoto, Masaru Nezu and Iwao Maeyama \\ Department of Orthopaedic Surgery, Tottori University School of Medicine.}

We experienced six cases of meniscal cysts, and recection was performed in five cases. Five cases were on the lateral side, and one on the medial side. Four cases were associated with meniscus tear and three cases with parrot-beak tear. Computed tomography was used in examining four cases. Cysts were recognized as low density areas. In diagnosing cysts computed tomography is very useful.

第62回本学会において半月板囊腫の 2 例を報告した が3)，その後症例を重ね 6 例の半月板囊腫を経験した ので，そのC T像等を加え，若干の文献的考察を加え て報告する.なお，内後方関節裂隙部に腫瘤形成を認 め, 半膜様筋滑液包炎と診断した 1 例についても報告 する.

\section{症例}

症例は年齢 31 才から 67 才で平均 43 才, 男 3 例, 女 3 例, 右膝 3 例, 左膝 3 例, 外側 5 例, 内側 1 例であっ た.

主訴はいずれも膝関節部の腫脹と疼痛であり, 関節 裂隙部に腫瘤形成を認めた。

単純 X線像で骨の潰瘍性変化を認めた症例はない. 関節造影像にて半月板損傷を認めたもの 2 例, 損傷を 否定できなかったもの1例, incomplete discoid 1 例, 半月板損傷を認めなかったもの 2 例であったが, 囊腫に造影剤の流入を認めた症例はなかった。4例に CT 撮影を行い, CT 像にて囊腫の発生部位に一致し $\tau, \mathrm{CT}$ 值+24 +40.6平均+33.9の低濃度領域を認 めた. 内部構造が均一な濃度のもの 2 例, 不均一な濃
度のもの 2 例, 境界が明瞭なもの 1 例, 不明瞭な部分 をともなうもの 3 例であった。

6 例中 5 例に関節鏡検査と手術を行い，いずれも半 月板と囊腫を一塊として摘出した. 内側例は半月板の 中後節部に発生しており，半月板損傷は認めなかった。 外側例 5 例中 2 例は前節部より膝蓋下脂肪体部にかけ， 大きな囊腫を形成しており，いずれも中節部に parrotbeak tear を認めた. 1 例は中後節部に発生しており, 中節部に parrot-beak tear を認めた. 1 例は中後節 部に発生しており, incomplete discoid であり中節部 に横断裂を認めた。これらの症例では肉眼的に半月板 の損傷部と囊腫の交通性を認めなかった. 手術を行っ ていない 1 例は外側中央部に腫瘤形成を認めたが，関 節造影像にて半月板損傷を認めなかった.

代表的な症例の CT 像を示す

症例：37才 男性

外側半月板前節部より膝蓋下脂肪体部にかけ, 大き な囊腫を形成しており，中節部に parrot-beak tear を認めた.

$\mathrm{CT}$ 像にて膝蓋下脂肪体部に内部構造が均一な濃度 で，境界不明瞭な部分をともなう， CT 值+40.6の低 
濃度領域を認めた（図 1 ）。

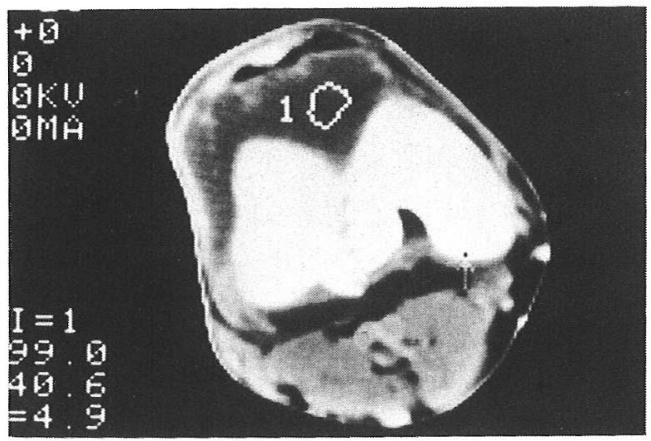

図137歳男, CT 像

滕蓋下脂肪体部に低濃度領域在認めた。

症例：36才 女性

外側中後節部に発生しており, incomplete discoid であり中節部に横断裂を認めた。

$\mathrm{CT}$ 像にて外後部に内部構造が均一な濃度で, 境界 不明瞭な部分をともなう, CT 值十24の低濃度領域を 認めた（図 2 ).

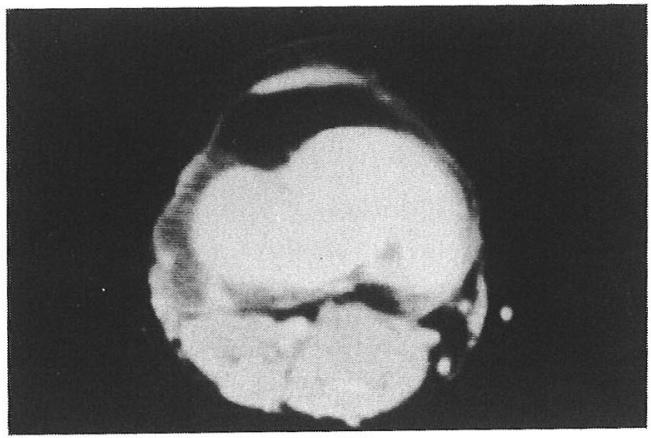

図 236 歳女, CT 像 外後部に低濃度領域を認めた。

次に半膜様筋滑液包炎と診断した症例の C T像を示 す.

症例：15才 男性

$\mathrm{CT}$ 像にて内後方部に内部構造が均一な濃度で, 境 界明瞭な CT 值十6 の低浱度領域を認めた（図 3 ).

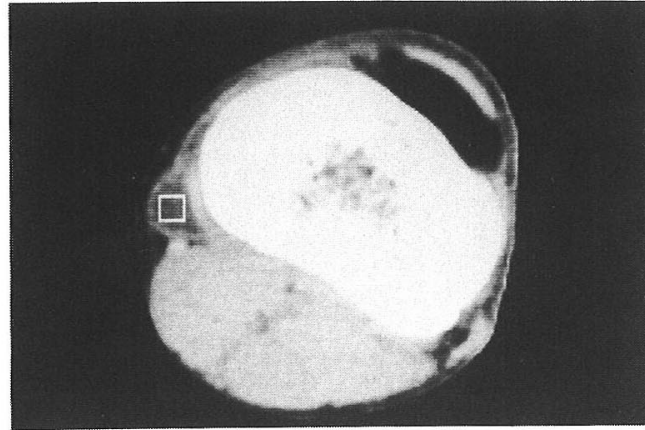

図 3 15歳男, CT 像 内後方部に低濃度領域を認めた。

考 察

Smillie $^{21}$ は半月板囊腫は半月板損傷をともなうもの が多く, 外側例 254 例中 218 例 $86 \%$, 内側例 83 例中62例 $75 \%$ に半月板損傷を認め, 特に parrot-beak tear が 多いと報告している. 我々の症例でも切除例 5 例中 4 例に半月板損傷を認め, 3 例が parrot-beak tear で あった。

そこで膝関節裂隙部に腫瘤を認めた場合，関節造影 や関節鏡にて半月板損傷を確認するてとは, 半月板囊 腫の診断に大切な所見と思われた. 我々の経験した症 例では, 関節造影像にて半月板損傷 2 例, 損傷を否定 できなかったもの1例，incomplete discoid 1 例を諗 め, 本症を疑う場合, さらに関節鏡検査を行う必要が あると思われた。

囊腫を疑って穿刺を行っても, 蜂巣状の場合内容物 がえられないととがあり, 膝関節周辺に発生する軟部

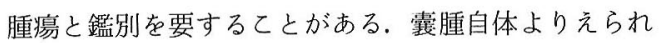
る情報を多くする目的で 4 例に CT 撮影を行った。C T 像にて囊腫の発生部位に一致して, CT 值+24〜+ 40.6 平均十33.9の低濃度領域を認めた。 内部構造が均 一な濃度のもの 2 例, 不均一な濃度のもの 2 例, 境界 が明膫なもの 1 例，不明瞭な部分をともなうもの 3 例 であった．乙れらの所見は他の部位におけるガングリ オンの CT 像と同様であった11. てれまで半月板囊腫 の CT 像の報告はなされていないが, 今回我々が経験 した症例では, CT 撮影は半月板囊腫の補助的診断価 值があると思われた。囊腫と半月板の関係は不明であ り, CT 像の方が摘出物より広範囲に描出されている ような印象を受けた症例も経験した。 
半膜様筋滑液包炎と診断した症例は, その発生部位 より, 半月板囊腫, 滕窩囊包との鑑別を要したが，C T像では区別できなかった。

\section{文献}

1) 古瀬清夫・他：CT 像からみた軟部腫陽および腫煌颣 似病変の評価, 整形外科Mook, 31：233-245, 1984.

2) Smillie, I. S.: Injuries of the Knee joint, 5th ed. Churchill Livingstone, Edinburghlondon and New york, 1978.

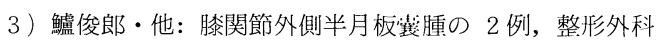
と災害外科, 31: 222-224, 1983.
質 問 九州労災病院 整形外科

1) 半月板囊腫という用語は, meniscal cyst, meniscus ganglion, Parameniscal cystという病態 をあらわしているが, 演者はてのうちどういう意味で 半月板囊腫という用語を用いられていますか.

2 ) 半月板断裂があった例を, そうでない例との病 態は異なると考えられていますか.

解 答鳥取大学 益永 恭光

1) 乙れらを一括して半月板囊腫としてあつかった.

2) 今回の症例では, 病態について検討していない. 